\title{
ANALISA DETEKSI HURUF HIJAIYAH MELALUI VOICE RECOGNITION MENGGUNAKAN KOMBINASI ENERGY Heriyanto
}

Teknik Informatika, Fakultas Teknologi Industri

Universitas Pembangunan Nasional "Veteran" Yogyakarta

Jln. Babarsari 2, Tambakbayan Yogyakarta

e-mail : mr_heriyanto_skom@yahoo.com

\begin{abstract}
Recognition of Letter hijaiyah represent early to comprehend Al-Quran reading bases. Learn to read Al-Quran at the time of studying still there are some jamaah in articulating hijaiyah letter sound still not yet correct precisely. uttering of the Letter hijaiyah felt by less precise, therefore correct how precise and say hijaiyah letter lafal can be analysed with recognition voice analysis. used Hijaiyah letter amount to 29. identifying hijaiyah letter pass recognition voice and count energy combination as a means of to know and detect lesson of hijaiyah letter how big mistake of said hijaiyah letter lafal reading can be known with software analyse hijaiyah letter with energy combination method recognition voice.
\end{abstract}

\section{Keywords : Alquran, Hijaiyah, kombinasi energy, voice recognition}

\section{Abstrak}

Pengenalan hruf hijaiyah merupakan awal untuk memahami dasar-dasar bacaan Al-Quran. Belajar membaca Al-Quran pada saat mengaji masih terdapat beberapa jamaah dalam melafalkan bunyi huruf hijaiyah masih belum tepat betul. Pengucapan huruf hijaiyah tersebut dirasa kurang tepat, oleh karena itu seberapa betul dan tepat mengucapkan lafal huruf hijaiyah dapat dianalisa dengan analisa voice recognition. Huruf-huruf hijaiyah yang digunakan berjumlah 29. Identifikasi huruf hijaiyah melalui voice recognition dan menghitung kombinasi energy sebagai alat untuk mengetahui dan mendeteksi pelajaran huruf hijaiyah seberapa besar kesalahan bacaan lafal huruf hijaiyah yang diucapkan dapat diketahui dengan software analisa huruf hijaiyah dengan voice recognition metode kombinasi energy.

Kata kunci : Al-Quran, hijaiyah, kombinasi energy, voice recognition

\section{PENDAHULUAN}

Pengenalan huruf hijaiyah merupakan awal untuk memahami dasar-dasar bacaan AlQuran. Belajar membaca Al-Quran pada saat mengaji masih terdapat beberapa jamaah dalam melafalkan bunyi huruf hijaiyah masih belum tepat betul. Pengucapan huruf hijaiyah tersebut dirasa kurang tepat, oleh karena itu seberapa betul dan tepat mengucapkan lafal huruf hijaiyah dapat dianalisa dengan analisa voice recognition. Huruf-huruf hijaiyah yang digunakan berjumlah 29. Apabila disebut huruf hijaiyah yang 28 maksudnya ialah huruf yang tersebut selain huruf alif (Zarkasyi, Imam, KH, 1995). identifikasi huruf hijaiyah melalui voice recognition dan menghitung kombinasi energy sebagai alat untuk mengetahui dan mendeteksi pelajaran huruf hijaiyah seberapa besar kesalahan bacaan lafal huruf hijaiyah yang diucapkan.

\section{TINJAUAN PUSTAKA}

a. Media Audio banyak cara untuk menganalisa yaitu (Lu, Guajun,1999):

1. Average Energy

$$
E=\frac{\sum_{n=0}^{N-1} x(n)^{2}}{N}
$$


2. Spectrum

Pada analisa spectrum maka dengan

Gambar

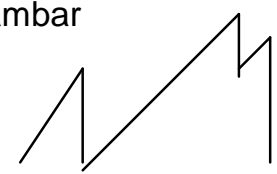

b. Suatu metode yang umum untuk ekstraksi fitur sinyal ucapan, yaitu Mel-Frequency Cepstrum Coefficients (MFCC) (Sakriani Sakti, et al 2004), akan digunakan dalam riset ini untuk lafal bacaan. Metode ini terbukti memiliki performan sangat bagus untuk berbagai bahasa di dunia.

c. Metode penghitungan Average Energy (Noertjahyana, Agustinus et al,2003), untuk menemukan sifat-sifat perbedaan dari lafal bacaan, tajwid dan mad dari sampling suara bacaan Al-Qur'an dengan orang yang berbeda tentunya sudah sesuai tartil, teknik SAPI mungkin sangat cocok untuk lafal bacaan.

d. Metode dengan Neuro Fuzzy untuk melakukan latihan berkali-kali untuk mengenal (TDS, Yohanes et al, 2002), akan digunakan dalam riset ini untuk bacaan Al-Qur'an.

e. Penelitian terdahulu dengan metode pengenalan penutur dibagi menjadi metode textindependent dan text dependent. Dalam sistem dengan ucapan bebas (text-independent), model penutur menangkap karakteristik wicara seseorang dengan kata yang bebas. Dalam sistem ucapan tertentu (text-dependent) pengenalan identitas penutur berdasarkan frasa yang spesifik seperti kata sandi (password), nomer kartu kredit, kode pin, dan sebaginya (Mustofa, Ali, 2007).

f. Tujuan dari pemroses MFCC (Mel Frequency Cepstrum Coefficient) menirukan perilaku dari pendengaran manusia. Adapun proses sebagai berikut (Mustofa, Ali, 2007):

\section{Frame blocking}

Sinyal wicara kontinyu diblok menjadi frame-frame $\mathrm{N}$ sampel, frame berdekatan dengan spasi $M(M<N)$. Frame pertama terdiri dari $N$ sampel pertama, frame kedua dengan $\mathrm{M}$ sampel setelah frame pertama dan overlap dengan $\mathrm{N}-\mathrm{M}$ sampel.

\section{Windowing}

Pada masing-masing frame individual untuk meminimalisasi sinyal tak kontinyu pada awal dan akhir masing-masing frame, windows dinyatakan sebagai $w(n), 0 \leq n N-1, N$ adalah jumlah sampel dari masing-masing frame. Jenis window yang digunakan adalah window Hamming.

\section{Transformasi Fourier Cepat}

FFT (Fast Fourier Transform) mengubah masing-masing N sampel dari domain waktu menjadi dosmain frekuensi. FFT adalah algoritma cepat untuk mengimplementasikan discrete fourier transform (DFT) dengan didefinisikan pada kumpulan (set) N sampel (Mustofa, Ali, 2007) .

\section{Mel-Frequency Wrapping}

Studi psikofisikal menunjukkan bahwa persepsi manusia dari kandungan frekuensi suara pada sinyal wicara tidak mengikuti skala linier. Untuk masing-masing nada dengan frekuensi actual, $\mathrm{f}$ dalam $\mathrm{Hz}$ pitch diukur dengan skala 'mel'. Skala mel-frequency adalah frekuensi linier berada di bawah $1000 \mathrm{~Hz}$ dan bentuk logaritmik berada diatas $1000 \mathrm{~Hz}$, sebagai titik referensi adalah pitch dengan tone $1 \mathrm{kHz}, 40 \mathrm{~dB}$ diatas nilai batas ambang pendengan ini dinyatakan 1000 mel (Mustofa, Ali, 2007) .

\section{Cepstrum}

Mengubah spectrum log mel menjadi domain waktu disebut MFCC (Mel frequency cepstrum coefficient) (Mustofa, Ali, 2007 ).

\section{Vektor Kuantisasi}

Vektor kuantisasi adalah proses memetakan vektor-vektor dari ruang vector besar menjadi jumlah terbatas daerah ruang vector. Masing-masing daerah disebut kluster dan dapat direpresentasikan oleh pusatnya yang disebut codeword (Mustofa, Ali, 2007).

\section{Pelatihan Vektor-Vektor}

Algoritma LBG (Linde, Buzo dan Gray) untuk kluster set L pelatihan vektor-vektor menjadi set $M$ codebook vektor-vektor. Algoritma ini secara formal diimplementasikan dengan prosedur rekursif (Mustofa, Ali, 2007 ). 
g. Penelitian yang lain menggunakan sistem neural network telah banyak diaplikasi untuk proses pengenalan suara atau pengenalan kata. Tapi beberapa kasus neural network belum dapat memberikan hasil yang baik (TDS, Yohanes et al,2002).Proses sampling suara merupakan sinyal suara manusia dalam domain waktu. Sinyal suara tersebut akan diubah ke dalam domain frekuensi dengan menggunakan Fast Fourier Transform (FFT) sehingga akan di dapatkan sinyal suara yang terpetakan dalam dalam spectrum frekuensi (TDS, Yohanes at al 2002).Tahap pertama dari sistem neuro-fuzzy adalah proses fuzzyfikasi. Nilai crisp dari setiap input data segmentasi sampel suara diubah menjadi variable fuzzy dan nilai gradenya (TDS, Yohanes at al, 2002). Dari hasil pengujian terlihat bahwa sistem neuro-fuzzy memberikan hasil yang lebih baik jika dibandingkan dengan sistem neuro network tanpa fuzzy (Sakriani Sakti at al, 2004). Waktu yang diperlukan untuk pengenalan lebih cepat dibandingkan dengan sistem neuro network sehingga dapat digunakan juga mencoba untuk bacaan Al-Qur'an.

h. Penelitian yang lain mengimplementasikan sistem pengenalan pembicaran dengan menggunakan SAPI 5.1 (Speech Application Programming Interface), engine Microsoft Speech Engine dan bahasa pemrograman Delphi5 yang digunakan untuk melakukan diktasi berbahasa Inggris pada aplikasi berbasis teks (Noertjahyana, Agustinus et al,2003). Terdapat dua macam mode pada pengenalan pembicaraan yaitu (Noertjahyana, Agustinus et al,2003) :

1. Mode Diktasi. Pada mode ini pengguna komputer dapat mengucapkan kata / kalimat yang selanjutnya akan dikenali oleh komputer dan diubah menjadi data teks. Keakuratan pengenalan mode ini bergantung pada pola suara dan akses pembicara serta pelatihan yang telah dilakukan.

2. Mode command and control pengguna komputer mengucapkan kata/kalimat yang sudah terdefinisi terlebih dahulu pada database dan selanjutnya akan digunakan untuk menjalankan perintah tertentu pada aplikasi komputer. Jumlah perintah yang dapat dikenali tergantung dari aplikasi yang telah mendefinisikan terlebih dahulu pada database jenis-jenis perintah yang dapat dieksekusikan. Mode ini merupakan speaker independent karena jumlah kata yang dikenali biasanya terbatas sekali dan ada kemungkinan pembicara tidak perlu melakukan pelatihan pada system sebelumnya. Salah satu kemudahan dengan ada pada SAPI dapat dipakai juga untuk mengenali bacaan Al-Quran yang berjenis lafal bacaan huruf hijaiyah.

Terdapat tiga macam metode yang dapat digunakan pada proses pemisahan kata ini yaitu : discrete speech, word spotting dan continuous speech. Pada discrete speech pengguna diharuskan mengucapkan kalimat secara terpenggal dengan adanya jeda sejenak diantara kata. Jeda digunakan system untuk mendeteksi awal dan akhir sebuah kata (Noertjahyana, Agustinus et al,2003).

Discrete speech ini mempunyai kelebihan yaitu sedikit resource (memori computer, waktu proses) yang digunakan oleh system untuk mendeteksi suara, tetapi mempunyai kelemahan yaitu ketidaknyamanan pengguna dalam mengucapkan kalimat. Pada word Spotting sebuah kalimat yang diucapkan pengguna system hanya mendeteksi kata yang terdapat di dalam perbendaharaan yang dimilikinya, dan mengabaikan kata-kata lain yang tidak dimilikinya. Kelemahan metode ini ialah besar kemungkinan system akan melakukan kesalahan arti pengenalan dalam bentuk kalimat. Tetapi metode ini mempunyai kelebihan yaitu pengguna dapat mengucapkan kalimat secara normal tanpa harus berhenti diantara kata. Pada metode continuous speech sistem akan mengenali dan memproses setiap kata yang diucapkan. Metode ini akan menghasilkan keakuratan dalam mengenali ucapan pengguna. Tetapi metode ini memerlukan resource yang besar dalam prosesnya. Pada metode ini system harus mendeteksi awal dan akhir setiap kata dalam kalimat tanpa adanya jeda diantara kata-kata (Noertjahyana, Agustinus et al,2003).

\section{i. DTW}

Algoritma DTW (Dynamic Time Warping) adalah algoritma mengukur kesamaan antara dua sekuensi yang dalam satu waktu dan sangat baik untuk adaptasi masalah komunikasi. (Ferrando et al., 2009).

j. FFT (Transformasi Fourier Cepat)

FFT (Fast Fourier Transform) mengubah masing-masing $\mathrm{N}$ sampel dari domain waktu menjadi dosmain frekuensi. FFT adalah algoritma cepat untuk mengimplementasikan discrete fourier transform (DFT) dengan didefinisikan pada kumpulan (set) $\mathrm{N}$ sampel 
(Mutofa, Ali, 2007).

k. Bahasan mengenai proses speech recognition ini adalah algoritma FFT (Fast fourier transform), yaitu algoritma yang cukup efisien dalam pemrosesan sinyal digital (dalam hal ini suara) dalam bentuk diskrit (Gressia Melissa, 2008)

\section{METODOLOGI PENELITIAN}

Metodologi rekayasa perangkat lunak yang digunakan model air terjun (waterfall model). Metode ini mempunyai pendekatan sekuensial yang sistematis yang meliput (Pressman, Roger, 2002) .
a. Rekayasa dan pemodelan sistem
b. Analisis kebutuhan perangkat lunak
c. Perancangan (desain)
d. Penulisan program (coding)
e. Pengujian (testing)
f. Pemeliharaan (maintenance)

\section{HASIL DAN PEMBAHASAN}

Pengolahan data dimulai dengan mengambil sampling file wave. Pada beberapa sample data suara diambil untuk dilakukan identifikasi awal. Pengidentifikasi awal dilakukan penghitungan Energy dan dilakukan kombinasi perhitungan energi untuk menemukan sifat-sifat perbedaan dari lafal bacaan hijaiyah dari sampling suara orang yang berbeda. Hasil tersebut dilakukan hitungan analisa 1 sampai 7 dengan rumus sebagai berikut :

Adapun tabel yang dibuat terdiri dari 3 tabel yaitu tabel thijaiyah digunakan untuk hurufhuruf hijaiyah sebanyah 29 , tabel tsound yang digunakan untuk mencatat data suara yang ada pada rekaman, tabel tanalisa digunakan untuk menganalisa data-data suara dan data energy yang ada. Berikut tabel thijaiyah seperti di bawah ini

Tabel 1. tabel thijaiyah

\begin{tabular}{|l|l|l|l|}
\hline Name Fields & Type Data & Size & Keterangan \\
\hline Kodehijaiyah & Text & 7 & Kode Hijaiyah \\
\hline Namahijaiyah & Text & 20 & Nama Hijaiyah \\
\hline Nilai_hitung & Number & 10 & Nilai \\
\hline Bobot_huruf & Number & 10 & Bobot \\
\hline Gambar & OLE Object & & Gambar hijaiyah \\
\hline & & & \\
\hline
\end{tabular}

Tabel tersebut berupa data masukan semua huruf hijaiyah yang ada dan jua dengan nila dan bobot yang ada diambil berdasarkan feature/ ciri yang di dapat.

Berikut data rekaman akan disimpan dalam tabel tsound yang ada mencatat energy, average energy, stereo kanan (posisi kanan) dan stereo kiri (posisi kiri). Data juga dicatat dengan mengambil wavenumber mono dan wave number stereo. Seperti pada tabel dibawah ini.

Tabel 2. tabel tsound

\begin{tabular}{|l|l|l|l|}
\hline Name Fields & Type Data & Size & Keterangan \\
\hline Average & Number & 10 & Average Energy \\
\hline Sample_awal & Number & 10 & Sampel awal \\
\hline Sample_akhir & Number & 10 & Sample akhir \\
\hline Posisi_kiri & Number & 10 & Posisi kiri stereo \\
\hline Posisi_kanan & Number & 10 & Posisi kanan stereo \\
\hline Nama_file & Text & 20 & Nama File \\
\hline Numsamples & Number & 10 & Nomor Sample \\
\hline Wavenumber & Number & 10 & Wave mono \\
\hline Wavenumber1 & Number & 10 & Wave Left stereo \\
\hline Wavenumber2 & Number & 10 & Wave Right stereo \\
\hline
\end{tabular}

Hasil data rekaman sampling suara yang diambil dapat dioleh untuk dilakukan proses perhitungan dengan disimpan dalam tabel tanalisa. Tabel tersebut menganalisa 1 sampai 
dengan analisa 7 untuk mendapatkan feature/ciri yang sesuai dengan hasil hitungan sepertipada pada tabel 3 di bawah ini

Tabel 3. Tabel tanalisa

\begin{tabular}{|l|l|l|l|}
\hline \multicolumn{1}{|c|}{ Name Fields } & Type Data & Size & \multicolumn{1}{c|}{ Keterangan } \\
\hline Average_analisa1 & Number & 10 & Hitungan analisa Average Energy \\
\hline analisa2 & Number & 10 & Hitungan analisa 2 \\
\hline analisa3 & Number & 10 & Hitungan analisa 3 \\
\hline analisa4 & Number & 10 & Hitungan analisa 4 \\
\hline analisa5 & Number & 10 & Hitungan analisa 5 \\
\hline analisa6 & Number & 10 & Hitungan analisa 6 \\
\hline analisa7 & Number & 10 & Hitungan analisa 7 \\
\hline Data_Nama_file & Text & 20 & Nama file dokumen penyimpanan \\
\hline
\end{tabular}

Hasil akhir di dapat dengan memadukan semua analisa yang ada dari analisa1, analisa 2 , analisa 3 , analisa 4 sampai dengan analisa 7 dan disimpan dalam file nama_file untuk mendapatkan kesamaan dengan tabel thijaiyah yang berupa nilai dan bobot.

Beriktu data gambar diagram level 0 sebagai berikut:

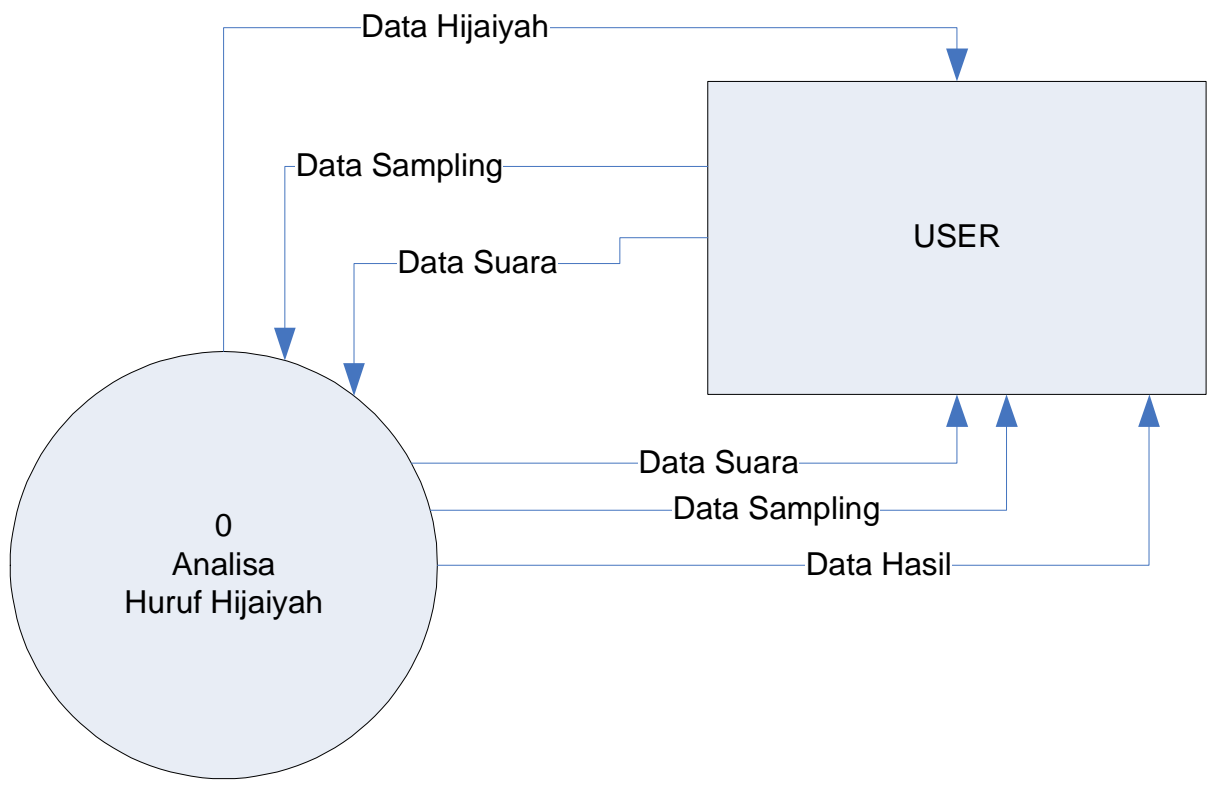

Gambar 1. DAD Level 0

Pada DAD Level 0 data yang diinputkan berupa suara manusia dan juga suara sampling. Suara sampling diambil untuk mencari feature dilakukan penelitian identifikasi berulang-ulang, sedangan data saura diambil on line saat untuk mengevaluasi ketepatan suara manusai dengan nilai feature yang didapat. Data hasil input huruf hijaiyah oleh user dapat diliha berupa data hijaiyah. Proses anlisa dilakukan dengan mencari feature yang ada pada huruf hijaiyah kemudian dalam bentuk nilai dan bobot yang dilakukan pengecekan oleh sistem analisa huruf hijaiyah dan kemudian menampilkan hasil olehan data berupa data huruf hijaiyah yang sesaui dengan nilai dan bobot yang mendekatai.

Berikut DAD Level 0 di lakukan penjabaran dengan dilakukan DAD Level 1 seperti pada gambar dibawah ini 

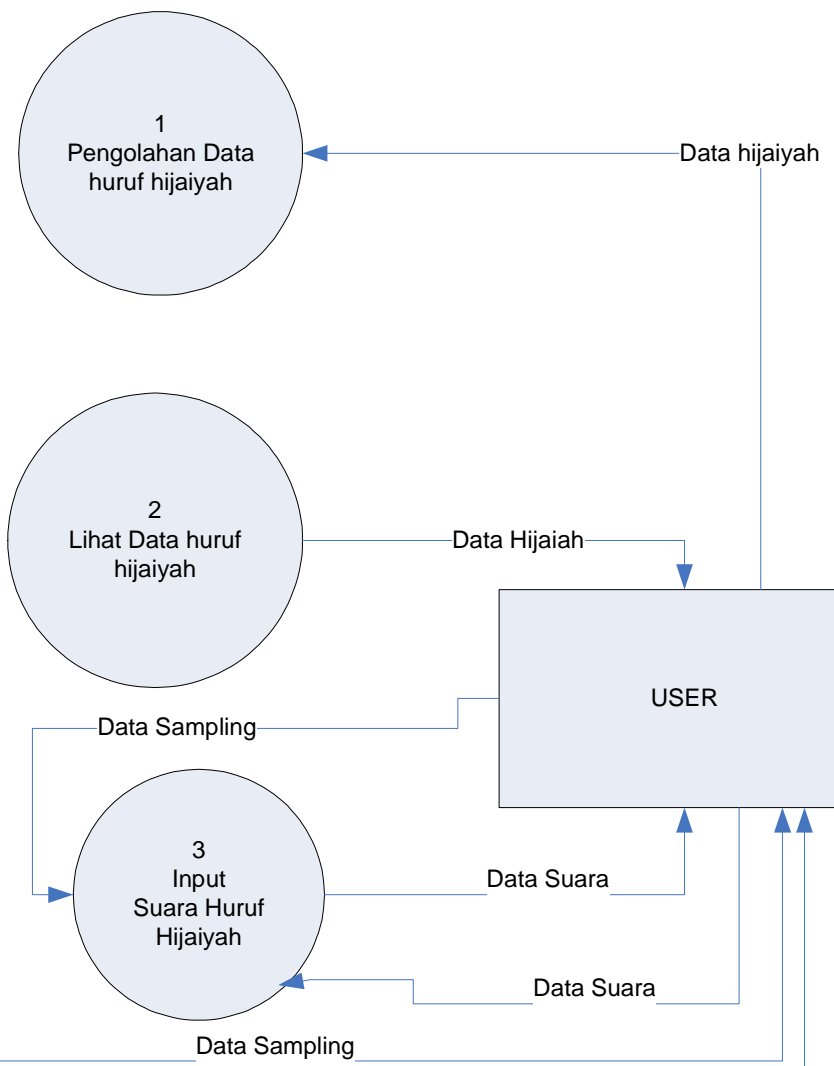

\section{USER}

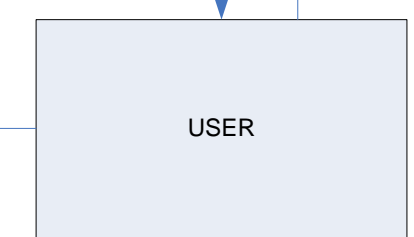

Data Suara

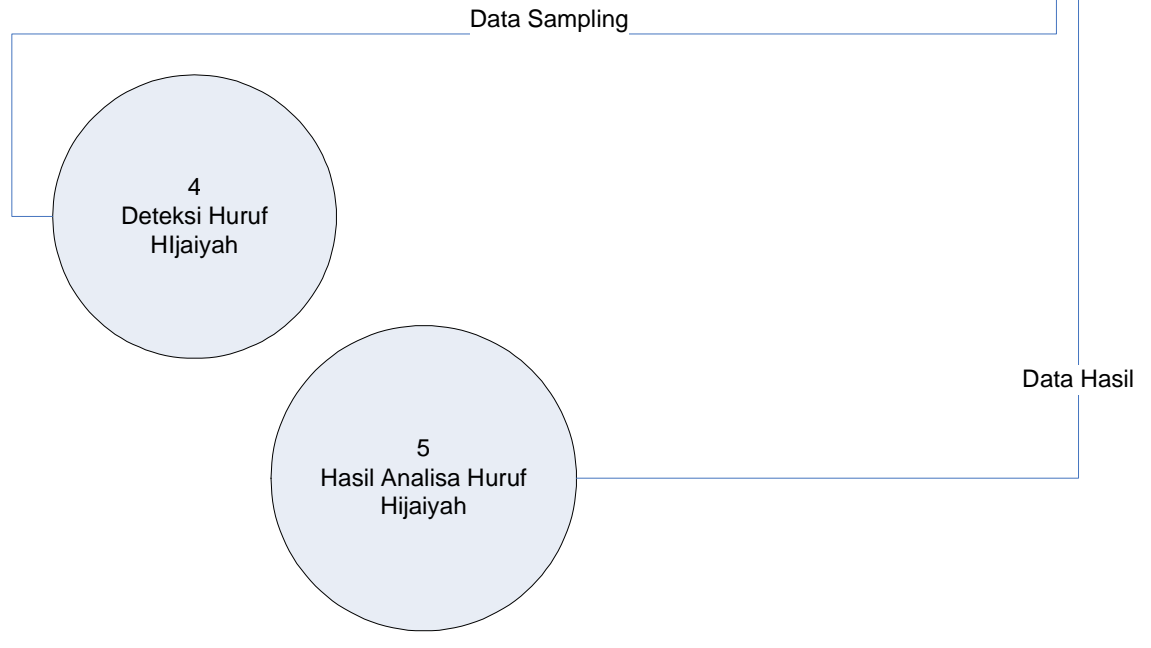

Gambar 2. DAD Level 1

Pada DAD Level 1user melakukan 5 aktifitas proses yaitu 1.pengolahan data hijaiyah, 2.lihat data hijaiyah, 3.input sampling, 4.deteksi dengan proses hitungan dan 5.hasil analisa tamplian huruf hijaiyah yang sesaui dengan analisa. Penjelasan masing-masing point proses akan dijelasakan pada DAD Level 1 sebagai berikut : 


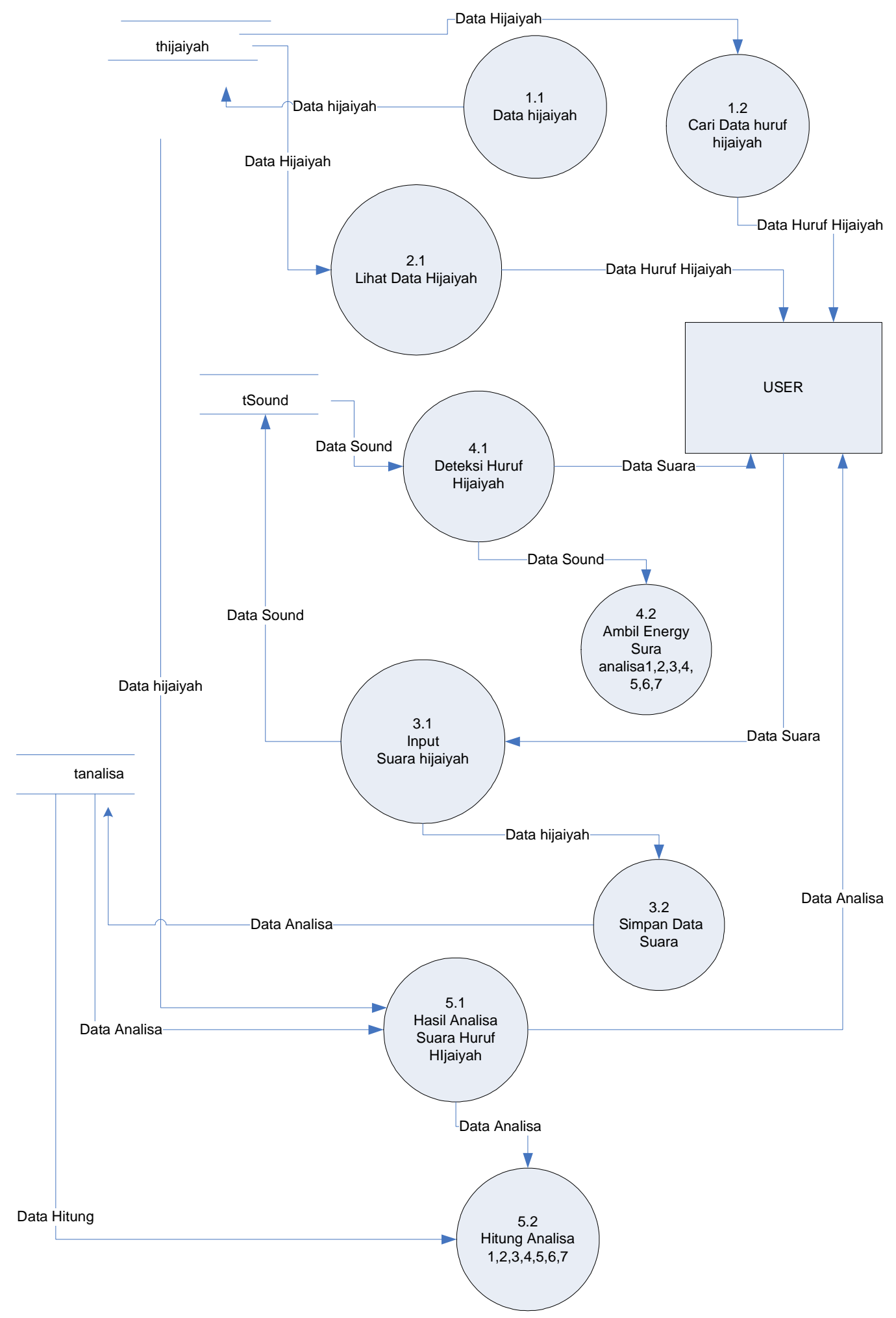

Gambar 3. DAD Level 2

Pada DAD Level 2 user melakukan aktifitas pada point 1 dijelaskan pada rincian 1.1 input data huruf hijayiah dan 1.2 cari data hijaiyah. Pada point 2 dijelaskan proses pada rincian 2.1, pada point 3 dijelasakan proses pada 3.1. dan 3.2, pada proses 4 dijelaskan pada proses 4.1 dan 4.2 dan proses 5 dijelaskan pada 5.1 dan 5.2 Berikut proses 1 dalam input huruf hijaiyah sebagai berikut : 


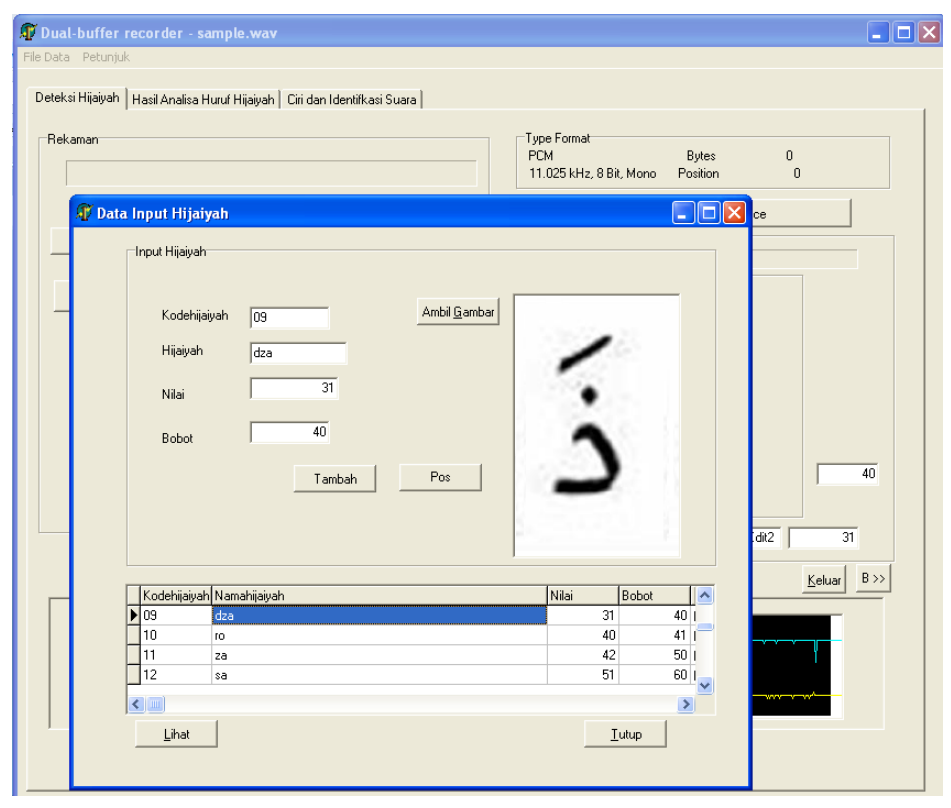

Gambar 4. Input huruf hijaiyah

Data diinputkan semua huruf hijaiyah sebanyak 29 disimpan dalam tabel thijaiyah.

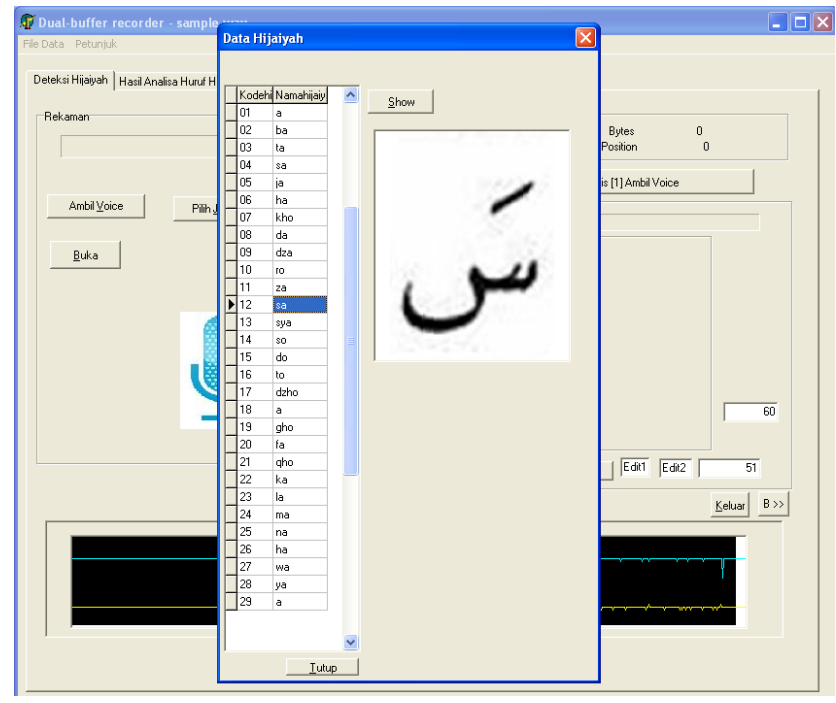

Gambar 5. Lihat huruf hijaiyah

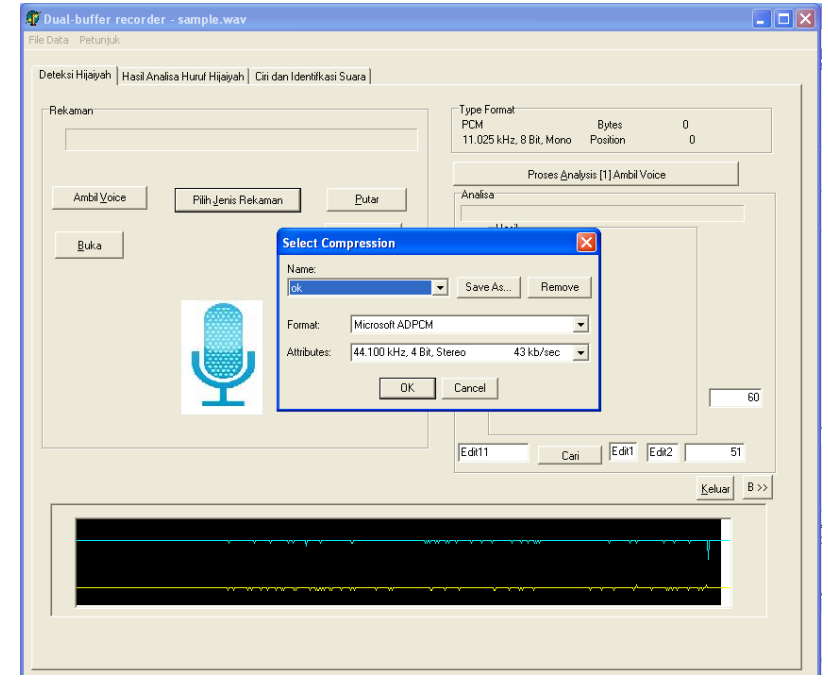

Gambar 6. Setting pengambilan rate data suara.

Pada saat pengambilan sampling huruf hijaiyah dilakuakn setting pengambilan rate dengan Microsoft ADPCM 44.100kHz, 4 Bit, Stereo $43 \mathrm{~kb} / \mathrm{sec}$. seperti pada gambar di bawah ini: 
Data yang diambil dilakukan perekaman seperti pada gambar di bawah ini :

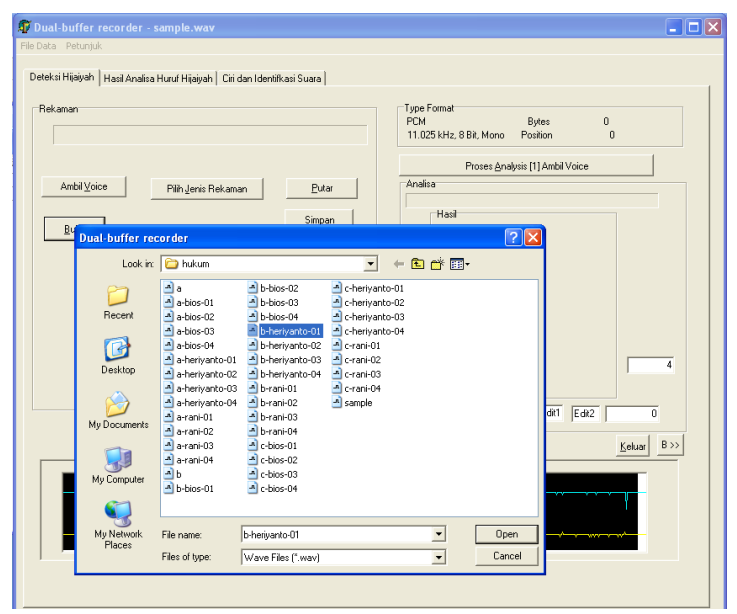

Gambar 7. Penyimpanan sampling rate

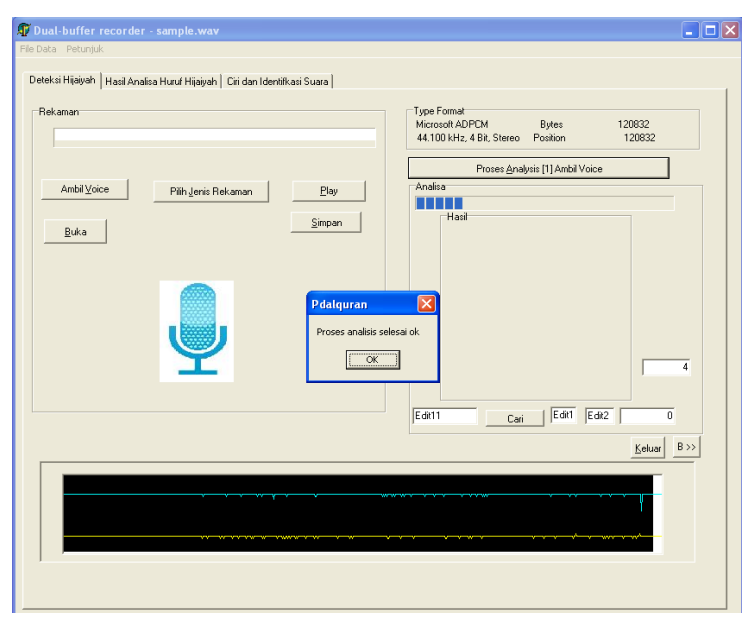

Gambar 8. Proses pengambilan sampling

Pengambilan sampling yang dilakukan berulang-ulang menghasilkan analisa berupa feature/ciri yang disimpan dalam nilai dan bobot. Selanjutkna dilakukan pengecekan anlasia dengan hitungan analisa 1 sampai 7 didapat mendekatai hasil yang dicari seperti pada gambar 7 dan 8 .

Analisa $1=$ jumlah (energy $=255)$ keseluruhan

Analisa 2 =jumlah (energy $=17$ ) keseluruhan

Analisa $3=$ jumlah(energy=255 dan 17) keseluruha kiri dan kanan

Analisa $4=$ jumlah (energy=255) posisi stereo kiri

Analisa $5=$ jumlah (energy $=255$ ) posisi stereo kanan

Analisa $6=$ jumlah (energy $=17$ ) posisi stereo kiri

Analisa 7 =jumlah (energy $=17$ ) posisi stereo kanan

Hasil proses perhitungan didapat kedekatan dengan feature yang ada pada thijaiyah sebagai berikut:
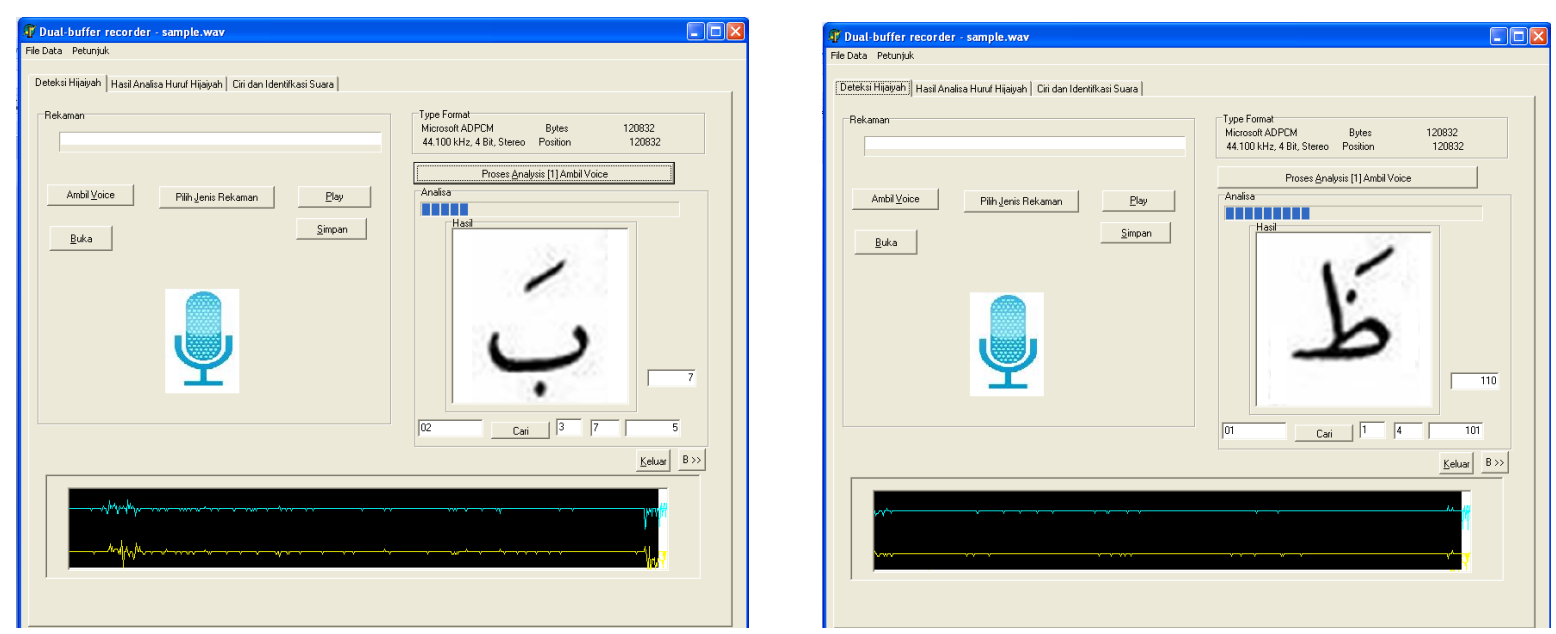

Gambar 9. Hasil proses perhitungan

Gambar 10. Hasil proses perhitungan ditemukan

Berikut daftar tabel percobaan data yang diperoleh untuk analisa huruf hijaiyah dapat dilihat pada tabel di bawah ini : 
Tabel 3 data analisa 1 dan 7 hasil percobaan

\begin{tabular}{|c|c|c|c|c|c|c|}
\hline analisa1 & analisa2 & analisa3 & analisa4 & analisa5 & analisa6 & analisa7 \\
\hline 75513033 & 9589 & 4674 & 72309894 & 78716192 & 7874 & 16155 \\
\hline 82248938 & 13484 & 26576 & 87428066 & 77069831 & 6099 & 3094 \\
\hline 255836495 & 30746 & 30918 & 259490039 & 252182969 & 8320 & 8274 \\
\hline 127060327 & 18124 & 30089 & 121162015 & 132958657 & 7010 & 4222 \\
\hline 117016313 & 4895 & 14365 & 116261046 & 117771600 & 23905 & 8145 \\
\hline 131266311 & 24597 & 21199 & 131090004 & 131442638 & 5336 & 6192 \\
\hline 59306554 & 17664 & 18 & 60522741 & 58090388 & 3357 & 3294808 \\
\hline 259018822 & 22506 & 43298 & 257026838 & 261010829 & 11508 & 5982 \\
\hline 105438616 & 8809 & 17920 & 101959053 & 108918198 & 11969 & 5883 \\
\hline 64240482 & 8700 & 22794 & 60797927 & 67683056 & 7383 & 2818 \\
\hline 253604387 & 30334 & 43990 & 260473832 & 246734964 & 8360 & 5765 \\
\hline 253604387 & 30334 & 43990 & 260473832 & 246734964 & 8360 & 5765 \\
\hline 253604387 & 30334 & 43990 & 260473832 & 246734964 & 8360 & 5765 \\
\hline 110342880 & 3173 & 18257 & 106448489 & 114237292 & 34775 & 6043 \\
\hline 110342880 & 3173 & 18257 & 106448489 & 114237292 & 34775 & 6043 \\
\hline 110342880 & 3173 & 18257 & 106448489 & 114237292 & 34775 & 6043 \\
\hline 440504637 & -1437 & 35680 & 437674282 & 443335028 & -306544 & 12345 \\
\hline 440504637 & -1437 & 35680 & 437674282 & 443335028 & -306544 & 12345 \\
\hline 504030359 & 20853 & 52595 & 503360475 & 504700302 & 24170 & 9583 \\
\hline 1413865022 & 68764 & 69737 & 1431781261 & 1395948868 & 20561 & 20274 \\
\hline-1971267611 & 116675 & 86879 & -1934765249 & -2007769862 & -16895 & -22689 \\
\hline 57808619 & -468 & 9003 & 52141120 & 63476137 & -123522 & 6421 \\
\hline 110342880 & 3173 & 18257 & 106448489 & 114237292 & 34775 & 6043 \\
\hline 110342880 & 3173 & 18257 & 106448489 & 114237292 & 34775 & 6043 \\
\hline 19081039 & 249 & -6 & 17478671 & 20683426 & 76630 & -3180173 \\
\hline 63525722 & 22290 & 16915 & 65686193 & 61365274 & 2849 & 3755 \\
\hline 70892024 & 17918 & 5355 & 65591922 & 76192148 & 3956 & 13238 \\
\hline 70892024 & 17918 & 5355 & 65591922 & 76192148 & 3956 & 13238 \\
\hline 70892024 & 17918 & 5355 & 65591922 & 76192148 & 3956 & 13238 \\
\hline 326995479 & 42944 & 25923 & 327173286 & 326817693 & 7614 & 12614 \\
\hline 559226292 & 5067 & 39902 & 617016198 & 501436400 & 110366 & 14014 \\
\hline 694090605 & 53089 & 47684 & 717155769 & 671025462 & 13074 & 14556 \\
\hline 694090605 & 53089 & 47684 & 717155769 & 671025462 & 13074 & 14556 \\
\hline 694090605 & 53089 & 47684 & 717155769 & 671025462 & 13074 & 14556 \\
\hline 694090605 & 53089 & 47684 & 717155769 & 671025462 & 13074 & 14556 \\
\hline 192466739 & 23897 & 8605 & 189002434 & 195931063 & 8054 & 22366 \\
\hline
\end{tabular}

Berikut hasil percobaan huruf hijaiyah yang diucapkan sebagai berikut : 
Tabel 4. Akurasi Percobaan Analisa 1-7

\begin{tabular}{|c|c|c|c|c|}
\hline No & $\begin{array}{c}\text { Huruf } \\
\text { Hijaiyah }\end{array}$ & Gamba & $\begin{array}{l}\text { Percobaan } \\
\text { Analisa 1-7 }\end{array}$ & akurasi \\
\hline 1 & Alif & i & 13 & $65 \%$ \\
\hline 2 & Ba' & ب & 14 & $66 \%$ \\
\hline 3 & Ta' & 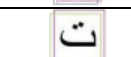 & 11 & $67 \%$ \\
\hline 4 & Sa' & 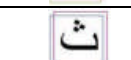 & 14 & $56 \%$ \\
\hline 5 & Jim & ج & 14 & $65 \%$ \\
\hline 6 & $\mathrm{Ha}$ & $\tau$ & 14 & $65 \%$ \\
\hline 7 & ho & $\dot{\tau}$ & 14 & $63 \%$ \\
\hline 8 & Dal & נI & 14 & $64 \%$ \\
\hline 9 & Dzal & $j$ & 13 & $63 \%$ \\
\hline 10 & Ro' & $\jmath$ & 13 & $60 \%$ \\
\hline 11 & Dzai & j & 13 & $61 \%$ \\
\hline 12 & $\operatorname{Sin}$ & س & 11 & $63 \%$ \\
\hline 13 & Syim & ثر & 12 & $56 \%$ \\
\hline 14 & Sad & ص & 11 & $57 \%$ \\
\hline 15 & Dad & ض & 13 & $55 \%$ \\
\hline 16 & Tho & ط & 14 & $58 \%$ \\
\hline 17 & Dzo & ظ & 14 & $62 \%$ \\
\hline 18 & Ain & $\varepsilon$ & 11 & $56 \%$ \\
\hline 19 & Ghoin & $\dot{\varepsilon}$ & 13 & $45 \%$ \\
\hline 20 & Fa' & فن & 13 & $48 \%$ \\
\hline 21 & Khof & ق & 12 & $49 \%$ \\
\hline 22 & Kaf & ك) & 11 & $49 \%$ \\
\hline 23 & Lam & $J$ & 12 & $50 \%$ \\
\hline 24 & Mim & 2 & 11 & $51 \%$ \\
\hline 25 & Nun & $\dot{ن}$ & 11 & $62 \%$ \\
\hline 26 & Waw & g & 12 & $60 \%$ \\
\hline 27 & $\mathrm{Ha}$ & $\Delta$ & 13 & $57 \%$ \\
\hline 28 & Hamzah & $c$ & 13 & $54 \%$ \\
\hline 29 & $\mathrm{Ya}$ & ي & 13 & $53 \%$ \\
\hline
\end{tabular}




\section{Perhitungan analisa 1 dan analisa 7 di kombinasi dengan dihitung rata-rata} menghasilkan jumlah kombinasi energy secara keseluruhan.

\section{KESIMPULAN}

Hasil dari identifikasi deteksi huruf hijaiyah didapat dengan voice recognition dengan metode sampling evarage energy, dan deviasi wave hitungan analisa analisa 1 sampai dengan analisa analisa 7 dan seterusnya masih mendekati kurang lebih $60 \%$ ketepatan dan keakuratannya. Pada orang yang sama dilakukan pengetesan terdapat ketepatan $62 \%$.

\section{DAFTAR PUSTAKA}

Ferrando, F., Nouveau, G., Philip, B., Pradeilles, P., Soulenq, V., Courmontagne, P., Pompidou, P. G. (2009). A voice recognition system for a submarine piloting.

Lu, Guajun,1999, Multimedia Database Manajemen Systems, Artech House,Inc

Mustofa, Ali, 2007,Sistem Pengenalan Penutur dengan Metode Mel-frequency Wrapping, Jurnal Teknik Elektro Vol.7 No.2 September 2007:88-96

Noertjahyana, Agustinus, Rudi Adipranata, 2003 Implementasi Sistem Pengenalan Suara Menggunakan SAPI 5.1 dan Delphi 5, Vol 4. No. 2 Jurnal Teknik Elektro Petra

Pressman, Roger, 2002, Rekayasa Perangkat Lunak, Jilid I, Andi Offset, Yogyakarta

Sakriani Sakti, Arry Akhmad Arman, Satoshi Nakamura,Paulus Hutagaol, 2004, Indonesian speech recognition for hearing and speaking impaired people. INTERSPEECH-2004, pp. 1037-1040.

TDS, Yohanes, Thiang, Suntono Chandra, 2002 Aplikasi Sistem Neuro-Fuzzy untuk Pengenalan Kata, Vol 2 No. 2,Jurnal Teknik Elektro Petra.

Zarkasyi, Imam, KH, 1995, Pelajaran Tajwid, Trimurti Press, Gontor Ponorogo 